\title{
Triterpenoid Saponins from Ardisia crenata and Their Inhibitory Activity on cAMP Phosphodiesterase
}

\author{
Zhonghua JIA, ${ }^{a}$ Kazuo Korke, ${ }^{a}$ Tamotsu NiKaido, ${ }^{a}$ Taichi Онмото, ${ }^{*, a}$ and Muyun Ni ${ }^{b}$ \\ Department of Pharmacognosy, School of Pharmaceutical Sciences, Toho University, ${ }^{a}$ 2-2-1 Miyama, Funabashi, \\ Chiba 274, Japan and Division of Chemistry, Institute of Chinese Materia Medica, China Academy of Traditional \\ Chinese Medicine, ${ }^{b}$ Beijing 100700, P. R. China. Received June 30, 1994; accepted August 3, 1994
}

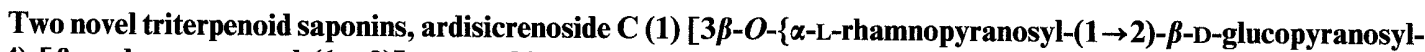
$(1 \rightarrow 4)$-[ $\beta$-D-glucopyranosyl-(1 $\rightarrow 2)]-\alpha$-L-arabinopyranosyl $\}-16 \alpha, 28$-dihydroxy-olean-12-en-30-oic acid 30- $O$ - $\beta$-Dglucopyranosyl ester $]$ and ardisicrenoside $D(2)[3 \beta-O-\{\beta$-D-xylopyranosyl-(1 $\rightarrow 2)-\beta$-D-glucopyranosyl-(1 $\rightarrow 4)-[\beta$-Dglucopyranosyl-(1 $\rightarrow 2)]$ - $\alpha$-L-arabinopyranosyl $\}-16 \alpha, 28$-dihydroxy-olean-12-en-30-oic acid 30-O- $\beta$-D-glucopyranosyl ester] were isolated from the roots of Ardisia crenata. Structure assignments are based on spectroscopic data including 2D-NMR (correlation spectroscopy (COSY), homonuclear Hartmann-Hahn spectroscopy (HOHAHA), heteronuclear correlated spectroscopy (HETCOR), heteronuclear multiple bond correlation (HMBC) and rotating frame NOE spectroscopy (ROESY)) experiments and some chemical reactions. In addition, the isolated saponins along with their prosapogenins and sapogenins have been evaluated for their inhibitory activity on cAMP phosphodiesterase as a primary screening test for new medicinal compounds.

Keywords Ardisia crenata; Myrsinaceae; root; triterpenoid saponin; ardisicrenoside C, D; cAMP phosphodiesterase inhibition

Ardisia crenata Sims is a widely occurring shrub in southern parts of China. Its roots have been used in the treatment of respiratory tract infections and menstrual disorders in Chinese traditional medicine, and showed significant anti-fertility effects in modern pharmacological studies. ${ }^{1)}$ Previous chemical studies showed that tri- terpenoid saponins were the main components of this genus. ${ }^{2-4)}$ Most recently, we reported the isolation and structure study of several triterpenoid saponins from $A$. crenata. ${ }^{5)}$ In this paper we wish to report the isolation and structure study of two additional triterpenoid saponins, ardisicrenosides C (1) and D (2) from this source as well

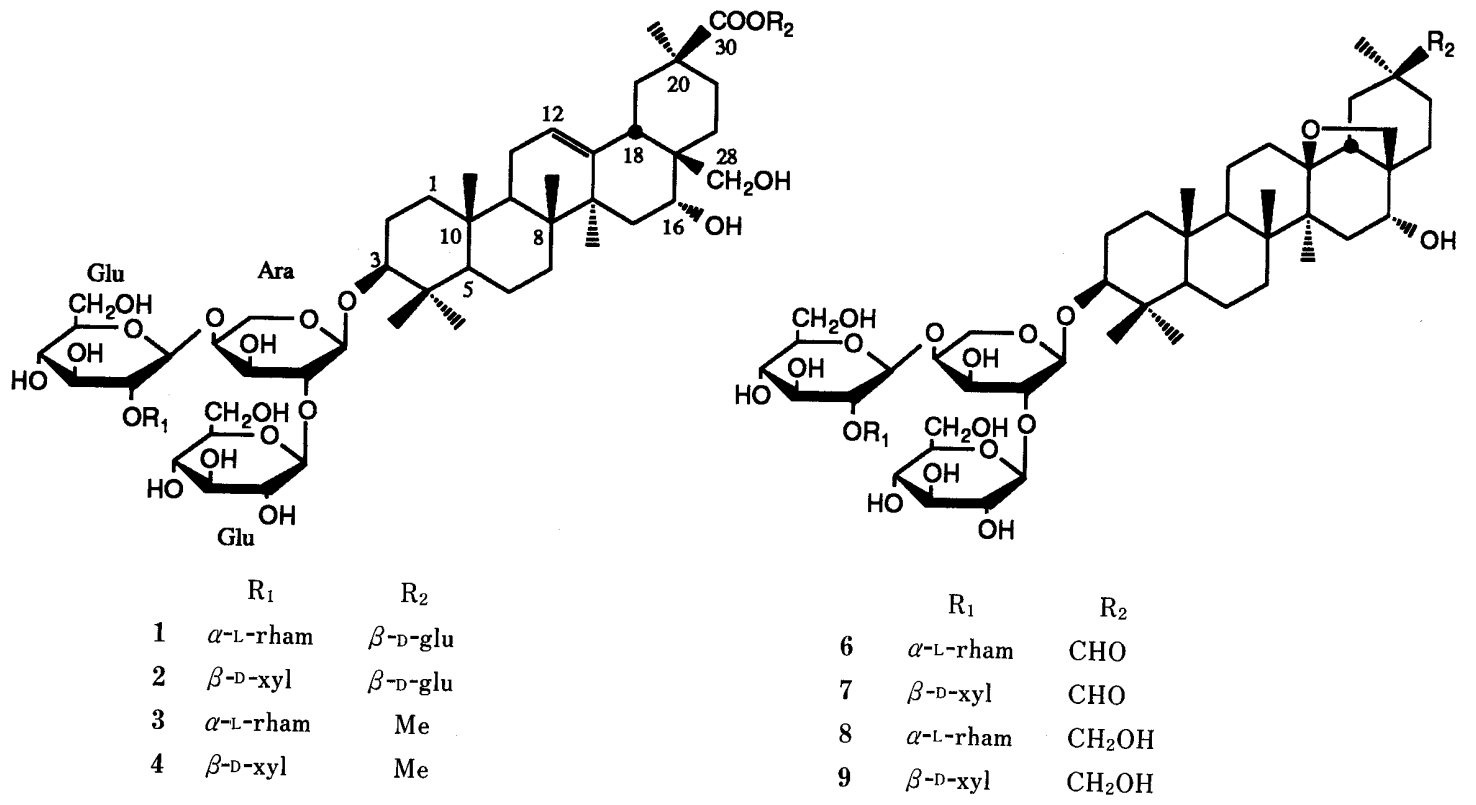

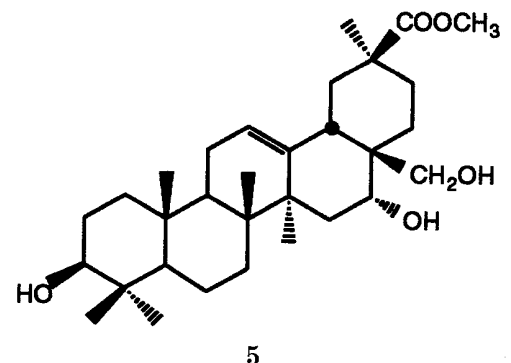

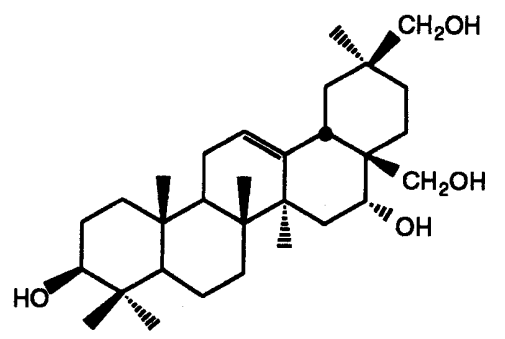


as their inhibitory activity on cAMP phosphodiesterase. Their structures were mainly elucidated on the basis of an extensive NMR study along with some chemical reactions.

\section{Results and Discussion}

The roots of $A$. crenata were defatted with petroleum ether, and then extracted with $\mathrm{CHCl}_{3}$, and $\mathrm{MeOH}$. Chromatography of the MeOH extract on Dianion HP-20, silica gel, octadecyl silica (ODS) and then after repeated HPLC purification over ODS furnished two further saponins, ardisicrenosides $\mathrm{C}(\mathbf{1})$ and $\mathrm{D}(\mathbf{2})$.

Ardisicrenoside C (1), white powder, mp $234-236^{\circ} \mathrm{C}$ (dec.), $[\alpha]_{\mathrm{D}}+4.8^{\circ}$. Its positive Liebermann-Burchard and Molish tests suggested it to be a triterpenoid glycoside. The elemental analysis combined with the FAB-MS quasimolecular ions (in positive mode) at $\mathrm{m} / \mathrm{z} 1253$ $[\mathrm{M}+\mathrm{H}]^{+}$and $1275[\mathrm{M}+\mathrm{Na}]^{+}$as well as ${ }^{13} \mathrm{C}$ and distortionless enhancement by polarization transfer (DEPT) NMR gave a molecular formula of $\mathrm{C}_{59} \mathrm{H}_{96} \mathrm{O}_{28}$. IR spectrum showed bands for hydroxyl $\left(3410 \mathrm{~cm}^{-1}\right)$, ester carbonyl $\left(1733 \mathrm{~cm}^{-1}\right)$, and double bond $\left(1635 \mathrm{~cm}^{-1}\right)$ groups. The ${ }^{13} \mathrm{C}-\mathrm{NMR}$ spectrum displayed 59 carbons, of which 30 were assigned to the aglycone part and 29 to the oligosaccharide moiety. The six $s p^{3}$ quaternary carbon signals at $\delta 15.4,16.4,16.7,27.1,27.9,28.3$ and the two $s p^{2}$ hybrid carbons at $\delta 122.8$ (d) and 144.3 (s) indicated that the aglycone was of an olean-12-en skeleton (Table I). Its ${ }^{1} \mathrm{H}$ and ${ }^{13} \mathrm{C}$-NMR displayed five sugar anomeric signals at $\delta 4.87(\mathrm{~d}, J=4.6 \mathrm{~Hz}), 5.12(\mathrm{~d}, 7.6), 5.25(\mathrm{~d}, 7.7)$, $6.24(\mathrm{~s}), 6.34(\mathrm{~d}, 8.0)$ and $\delta 101.3,102.8,104.1,104.9$, and 95.5, respectively (Tables II and III). The resonance at $\delta$ 95.5 indicated that an ester bond linkage existed in 1. Alkaline treatment using dilute sodium methoxide in $\mathrm{MeOH}$ resulted in a prosapogenin methyl ester (3) and a monosaccharide, identified by GLC analysis to be glucose. The ${ }^{1} \mathrm{H}$ - and ${ }^{13} \mathrm{C}$ NMR spectra showed that compound 3 consisted of four sugar units (Table II). Acidic hydrolysis of compound 3 in $1 \mathrm{~N} \mathrm{HCl}\left(\mathrm{MeOH}-\mathrm{H}_{2} \mathrm{O}, 1: 1\right)$ yielded compound 5. The ${ }^{13} \mathrm{C}$ NMR data of 5 was similar to that of the known compound, cyclamiretin D. ${ }^{6)}$ As data in Table I shows compound 5 lacked the resonance due to the aldehydic group at C-20 of cyclamiretin D, but instead exhibited a signal arising from the carboxyl carbon at $\delta$ 178.2. As in cyclamiretin $\mathrm{D}$, the existence of hydroxyl groups at C-3 and C-16 was deduced from the ${ }^{13} \mathrm{C}-\mathrm{NMR}$ resonances at $\delta 78.1$ (C-3) and 73.9 (C-16). The stereochemistry was inferred from the rotating frame Overhauser enhancement spectroscopy (ROESY) experiment of 1. The spatial proximities observed between $\mathrm{H}-3$ $(\delta 3.12)$ and $\mathrm{H}-23(\delta 1.11), \mathrm{H}-3$ and $\mathrm{H}-5(\delta 0.67)$, and $\mathrm{H}-16$ $(\delta 4.58)$ and $\mathrm{H}-28(\delta 3.54,3.63)$ indicated the $\beta$ orientation of the hydroxyl at $\mathrm{C}-3$ and the $\alpha$ orientation at $\mathrm{C}-16$. The stereochemistry at $\mathrm{C}-20$ could be deduced from a biosynthesis view. We earlier reported the structure study of an artifactual sapogenin (10) from the acidic hydrolysis of ardisicrenosides $\mathrm{A}$ and $\mathrm{B}^{5)}$ The $\beta$-hydromethyl group at C-20 was clearly established from their ROESY experiments. Accordingly, the carboxyl carbons of 1 and 5 were assigned to be $\beta$ orientation and numbered C-30. On the basis of the above evidence and the information from FAB and EI-MS spectra, compound 5 was identified as $3 \beta, 16 \alpha, 28$-trihydroxy-12-olean-30-oic acid methyl ester (jacquinic acid methyl ester). ${ }^{7)}$ The monosaccharides were shown to be arabinose, glucose and rhamnose $(1: 2: 1)$ by GLC analysis. The ${ }^{13} \mathrm{C}-\mathrm{NMR}$ data difference between compounds 1, 3 and $\mathbf{5}$ combined with the above analysis indicated that ardisicrenoside $\mathrm{C}$ was a bidesmosidic saponin, and that one of the glucoses was attached to the C-30 of the aglycone through an ester bond while the other four, in a chain, were connected to C-3 position of the aglycone through an ether bond.

The nature of the monosaccharides and sequence of the oligosaccharide chain can be determined by means of ${ }^{1} \mathrm{H}-{ }^{1} \mathrm{H}$ shift correlation spectroscopy (COSY), homonuclear Hartmann-Hahn spectroscopy (HOHAHA), ${ }^{13} \mathrm{C}-{ }^{1} \mathrm{H}$ heteronuclear correlated spectroscopy (HETCOR), heteronuclear multiple bond correlation (HMBC) ${ }^{9)}$ and ROESY ${ }^{10)}$ experiments. Starting from the anomeric protons of each sugar unit, all the hydrogens within each spin system could be identified using COSY with the aid of the 2D-HOHAHA spectrum. On the basis of the assigned hydrogens, ${ }^{13} \mathrm{C}$ resonances of each sugar unit were assigned by HETCOR and further confirmed by HMBC experiment.

The anomeric configurations and ring sizes of each sugar can be obtained from reading the $\mathrm{H}-1$ vicinal coupling constants $\left({ }^{3} J_{\mathrm{H} 1, \mathrm{H} 2}\right)$ and by comparing their ${ }^{13} \mathrm{C}-\mathrm{NMR}$ data with those of the published methyl glycosides. ${ }^{11,12)}$ All the monosaccharides in the pyranose forms were determined from their ${ }^{13} \mathrm{C}-\mathrm{NMR}$ data. The $\beta$ anomeric configurations for all the glucoses were easily seen from their relatively large ${ }^{3} J_{\mathrm{H} 1, \mathrm{H} 2}$ coupling constants $(7-8 \mathrm{~Hz})$. The $\alpha$ configuration in the rhamnose residue was clear from its $\mathrm{H}-1$ non-splitting pattern and its distinct C-3, 5 chemical shift difference from that of methyl $\beta$-L-rhamnopyranoside. ${ }^{11)}$ The medium magnitude of the ${ }^{3} J_{\mathrm{H} 1, \mathrm{H} 2}$ $(4.6 \mathrm{~Hz})$ coupling constant of the arabinose made its anomeric configuration assignment equivocal. At first glance, the similarity of this value to that of methyl $\beta$ L-arabinofuranoside $(4 \mathrm{~Hz})$ seemed to have provided the answer. ${ }^{13)}$ However, a detailed analysis of the ROESY showed that strong through-space interactions existed between $\mathrm{H}-1, \mathrm{H}-3$ and $\mathrm{H}-5$. Such nuclear Overhauser effects (NOEs) could not be reflected from an arabinose in either the $\beta$-L-pyran or -furan forms, thus ruling out the possibility of being the $\beta$-L form. In fact, the NOEs between $\mathrm{H}-1, \mathrm{H}-3$ and $\mathrm{H}-5$ indicated that the arabinose should adopt an $\alpha$ orientation at its anomeric carbon ${ }^{14)}$ and the small ${ }^{3} J_{\mathrm{H} 1, \mathrm{H} 2}$ coupling constant could be explained by the quick conformational equilibrium between its ${ }^{4} \mathrm{C}_{1}$ and ${ }^{1} \mathrm{C}_{4}$ conformers. ${ }^{15)}$ The absolute configurations of these monosaccharides were chosen in keeping with those most commonly encountered among plant glycosides. From these results, the five sugars in ardisicrenoside $\mathbf{C}(\mathbf{1})$ were determined to be an $\alpha$-L-arabinopyranose, three $\beta$-D-glucopyranoses, and an $\alpha$-L-rhamnopyranose.

Information about the sequence of the tetrasaccharide chain at the $\mathrm{C}-3$ position of the aglycone was deduced from the following study. From the completely assigned ${ }^{13} \mathrm{C}-\mathrm{NMR}$, the branched nature of the sugar moiety was evident, and the noticeable ${ }^{13} \mathrm{C}$ shift differences between individual sugar residues and model compounds suggested 
TABle I. ${ }^{1,3} \mathrm{C}-\mathrm{NMR}$ Data for the Aglycone Parts of Compounds 1, 2 , 3, 4, and 5 (in $\mathrm{C}_{5} \mathrm{D}_{5} \mathrm{~N}, \delta$ )

\begin{tabular}{|c|c|c|c|c|c|c|}
\hline Carbon & $1^{a)}$ & $2^{a)}$ & 3 & 4 & 5 & DEPT \\
\hline 1 & 38.7 & 38.8 & 38.7 & 38.5 & 39.2 & $\mathrm{CH}_{2}$ \\
\hline 2 & 26.1 & 26.3 & 26.1 & 26.0 & 28.2 & $\mathrm{CH}_{2}$ \\
\hline 3 & 88.9 & 88.9 & 88.9 & 88.3 & 78.1 & $\mathrm{CH}_{2}$ \\
\hline 4 & 39.2 & 39.5 & 39.2 & 39.2 & 39.5 & $\mathrm{C}^{-2}$ \\
\hline 5 & 55.5 & 55.8 & 55.6 & 55.6 & 55.9 & $\mathrm{CH}$ \\
\hline 6 & 18.2 & 18.4 & 18.2 & 18.1 & 18.8 & $\mathrm{CH}_{2}$ \\
\hline 7 & 32.9 & 33.1 & 32.9 & 32.8 & 33.4 & $\mathrm{CH}_{2}$ \\
\hline 8 & 39.8 & 39.9 & 39.8 & 39.7 & 40.1 & $\mathrm{C}$ \\
\hline 9 & 46.8 & 47.0 & 46.8 & 46.8 & 47.3 & $\mathrm{CH}$ \\
\hline 10 & 36.6 & 36.8 & 36.6 & 36.5 & 37.3 & C \\
\hline 11 & 23.5 & 23.7 & 23.5 & 23.4 & 23.9 & $\mathrm{CH}_{2}$ \\
\hline 12 & 122.8 & 122.9 & 122.6 & 122.5 & 122.9 & $\mathrm{CH}$ \\
\hline 13 & 144.3 & 144.5 & 144.5 & 144.3 & 144.9 & $\mathrm{C}$ \\
\hline 14 & 41.5 & 41.7 & 41.6 & 41.4 & 41.9 & $\mathrm{C}$ \\
\hline 15 & 34.6 & 34.8 & 34.5 & 34.3 & 34.9 & $\mathrm{CH}_{2}$ \\
\hline 16 & 73.7 & 74.1 & 73.4 & 73.3 & 73.9 & $\mathrm{CH}$ \\
\hline 17 & 40.1 & 40.3 & 40.0 & 39.9 & 40.4 & $\mathrm{C}$ \\
\hline 18 & 43.0 & 43.2 & 43.8 & 43.7 & 44.1 & $\mathrm{CH}$ \\
\hline 19 & 44.3 & 44.5 & 44.2 & 44.0 & 44.6 & $\mathrm{CH}_{2}$ \\
\hline 20 & 44.4 & 44.6 & 44.4 & 44.3 & 44.7 & $\mathrm{C}$ \\
\hline 21 & 33.3 & 33.5 & 33.4 & 33.2 & 33.9 & $\mathrm{CH}_{2}$ \\
\hline 22 & 31.5 & 31.7 & 32.0 & 31.8 & 32.4 & $\mathrm{CH}_{2}$ \\
\hline 23 & 27.9 & 28.1 & 27.9 & 27.7 & 28.8 & $\mathrm{CH}_{3}$ \\
\hline 24 & 16.4 & 16.7 & 16.4 & 16.4 & 16.6 & $\mathrm{CH}_{3}$ \\
\hline 25 & 15.4 & 15.6 & 15.4 & 15.3 & 15.9 & $\mathrm{CH}_{3}$ \\
\hline 26 & 16.7 & 16.9 & 16.7 & 16.5 & 17.1 & $\mathrm{CH}_{3}$ \\
\hline 27 & 27.1 & 27.3 & 27.1 & 26.9 & 27.5 & $\mathrm{CH}_{3}$ \\
\hline 28 & 69.8 & 69.9 & 70.3 & 70.2 & 70.7 & $\mathrm{CH}_{2}$ \\
\hline 29 & 28.3 & 28.6 & 28.4 & 28.3 & 28.8 & $\mathrm{CH}_{3}$ \\
\hline \multirow[t]{2}{*}{30} & 176.9 & 177.0 & 178.0 & 177.9 & 178.2 & $\mathrm{C}$ \\
\hline & & & $\begin{array}{c}\mathrm{C}_{30} \mathrm{OOMe} \\
51.2\end{array}$ & $\begin{array}{c}\mathrm{C}_{30} \mathrm{OOMc} \\
51.0\end{array}$ & $\begin{array}{c}\mathrm{C}_{30} \mathrm{OOMc} \\
51.4\end{array}$ & $\mathrm{CH}_{3}$ \\
\hline
\end{tabular}

a) Assignment based upon COSY, HOHAHA, HETCOR, and HMBC experiments.

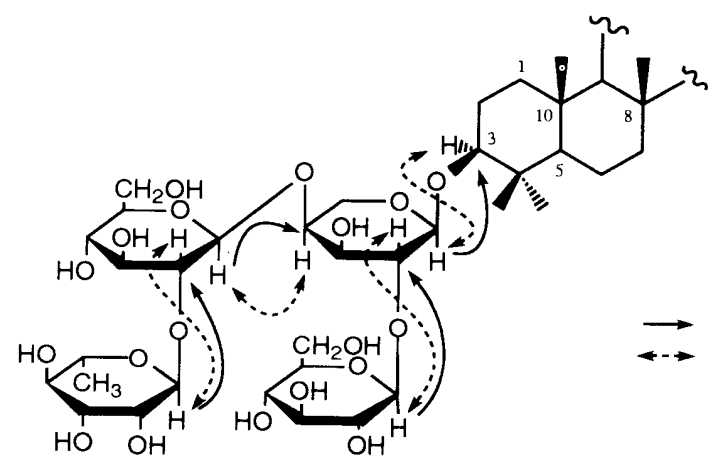

HMBC NOE

Fig. 1. The HMBC and NOE Correlations Observed in Ardisicrenoside C (1)

that arabinose was the branched center, while rhamnose and one of the glucoses were in the terminal positions. Two experiments (HMBC and ROESY) were employed to establish the interglycosidic linkages. In HMBC the mixing time was optimized at $8 \mathrm{~Hz}$ ), the following interresidue correlations were observed: $\mathrm{H}-1$ of rhamnose with $\mathrm{C}-2$ of the inner glucose; $\mathrm{H}-1$ of the inner glucose with $\mathrm{C}-4$ of arabinose; and $\mathrm{H}-1$ of the terminal glucose with $\mathrm{C}-2$ of arabinose. The same conclusion was drawn from the ROESY experiment (Table III). The attachment of the oligosaccharide chain to $\mathrm{C}-3$ of the aglycone was further indicated by the ${ }^{13} \mathrm{C}$ shift differences $(\Delta 10.7)$
TABLE II. ${ }^{13} \mathrm{C}-\mathrm{NMR}$ Data for the Sugar Moieties of Compounds 1 , 2,3 and 4 (in $\mathrm{C}_{5} \mathrm{D}_{5} \mathrm{~N}, \delta$ )

\begin{tabular}{|c|c|c|c|c|c|}
\hline Sugar unit & $1^{a)}$ & $2^{a)}$ & 3 & 4 & DEPT \\
\hline \multicolumn{6}{|l|}{ 3-O-Sugar } \\
\hline \multicolumn{6}{|c|}{ Arabinose (A) } \\
\hline A-1 & 104.1 & 104.6 & 104.2 & 104.3 & $\mathrm{CH}$ \\
\hline A-2 & 80.2 & 79.7 & 80.2 & 79.3 & $\mathrm{CH}$ \\
\hline A-3 & 71.8 & 73.2 & 71.8 & 72.7 & $\mathrm{CH}$ \\
\hline A-4 & 74.5 & 78.5 & 74.5 & 78.2 & $\mathrm{CH}$ \\
\hline$A-5$ & 63.2 & 64.2 & 63.4 & 63.9 & $\mathrm{CH}_{2}$ \\
\hline \multicolumn{5}{|l|}{ Glucose (G) } & \\
\hline $\mathrm{G}-1$ & 104.9 & 104.8 & 104.9 & 104.4 & $\mathrm{CH}$ \\
\hline $\mathrm{G}-2$ & 75.9 & 76.1 & 76.0 & 75.6 & $\mathrm{CH}$ \\
\hline $\mathrm{G}-3$ & 77.5 & 78.1 & 77.6 & 77.4 & $\mathrm{CH}$ \\
\hline $\mathrm{G}-4$ & 71.3 & 71.0 & 71.3 & 70.6 & $\mathrm{CH}$ \\
\hline G-5 & 77.7 & 77.8 & 77.7 & 77.1 & $\mathrm{CH}$ \\
\hline G-6 & 62.4 & 62.9 & 62.4 & 62.4 & $\mathrm{CH}_{2}$ \\
\hline \multicolumn{6}{|l|}{$\begin{array}{l}\text { Glucose }\left(\mathrm{G}^{\prime}\right) \\
\text { (Inner) }\end{array}$} \\
\hline$G^{\prime}-1$ & 102.8 & 104.1 & 102.8 & 103.7 & $\mathrm{CH}$ \\
\hline$G^{\prime}-2$ & 77.2 & 85.2 & 77.2 & 84.8 & $\mathrm{CH}$ \\
\hline$G^{\prime}-3$ & 79.0 & 77.4 & 79.0 & 77.0 & $\mathrm{CH}$ \\
\hline $\mathrm{G}^{\prime}-4$ & 71.5 & 71.8 & 71.5 & 71.3 & $\mathrm{CH}$ \\
\hline$G^{\prime}-5$ & 77.9 & 78.2 & 77.9 & 77.5 & $\mathrm{CH}$ \\
\hline$G^{\prime}-6$ & 62.2 & 62.3 & 62.3 & 61.8 & $\mathrm{CH}_{2}$ \\
\hline \multicolumn{6}{|c|}{ Rhamnose (R) } \\
\hline R-1 & 101.3 & & 101.3 & & $\mathrm{CH}$ \\
\hline $\mathrm{R}-2$ & 71.9 & & 71.9 & & $\mathrm{CH}$ \\
\hline $\mathrm{R}-3$ & 72.2 & & 72.3 & & $\mathrm{CH}$ \\
\hline $\mathrm{R}-4$ & 74.3 & & 74.4 & & $\mathrm{CH}$ \\
\hline$R-5$ & 69.2 & & 69.2 & & $\mathrm{CH}$ \\
\hline$R-6$ & 18.3 & & 18.5 & & $\mathrm{CH}_{3}$ \\
\hline \multicolumn{6}{|l|}{ Xylose (X) } \\
\hline$X-1$ & & 107.5 & & 107.1 & $\mathrm{CH}$ \\
\hline$X-2$ & & 75.9 & & 75.4 & $\mathrm{CH}$ \\
\hline$X-3$ & & 77.7 & & 77.1 & $\mathrm{CH}$ \\
\hline$X-4$ & & 70.6 & & 70.2 & $\mathrm{CH}$ \\
\hline$X-5$ & & 67.3 & & 66.9 & $\mathrm{CH}_{2}$ \\
\hline \multicolumn{6}{|l|}{ 30-O-Sugar } \\
\hline \multicolumn{6}{|l|}{ Glucose $\left(G^{\prime \prime}\right)$} \\
\hline$G^{\prime \prime}-1$ & 95.5 & 95.8 & & & $\mathrm{CH}$ \\
\hline$G^{\prime \prime}-2$ & 74.0 & 74.3 & & & $\mathrm{CH}$ \\
\hline$G^{\prime \prime}-3$ & 78.2 & 78.5 & & & $\mathrm{CH}$ \\
\hline$G^{\prime \prime}-4$ & 70.9 & 71.2 & & & $\mathrm{CH}$ \\
\hline$G^{\prime \prime}-5$ & 78.9 & 79.2 & & & $\mathrm{CH}$ \\
\hline$G^{\prime \prime}-6$ & 62.0 & 62.3 & & & $\mathrm{CH}_{2}$ \\
\hline
\end{tabular}

a) Assignments based upon COSY, HOHAHA, HETCOR and HMBC experiments.

between the ardisicrenoside $\mathrm{C}(\mathbf{1})$ and its freed aglycone 5. Moreover, the correlation between $\mathrm{H}-1$ of arabinose and $\mathrm{C}-3$ of aglycone in $\mathrm{HMBC}$ and the result from ROESY also reached the same conclusion (Table III, Fig. 1). In addition, the correlation existed between $\delta 6.34(\mathrm{H}-1$ of one of the glucoses) and 176.9 (C-30 of the aglycone) in $\mathrm{HMBC}$ substantiated the early conclusion that one of the glucoses was located at C-30 through an ester bond. From the foregoing evidence, the structure of ardisicrenoside $\mathrm{C}$ (1) was elucidated as $3 \beta-O-\{\alpha-\mathrm{L}-\mathrm{rhamnopyranosyl}-(1 \rightarrow 2)$ $\beta$-D-glucopyranosyl-( $1 \rightarrow 4)$-[ $\beta$-D-glucopyranosyl- $(1 \rightarrow 2)]$ $\alpha$-L-arabinopyranosyl $\}-16 \alpha, 28$-dihydroxy-olean-12-en-30oic acid 30- $O-\beta$-D-glucopyranosyl ester.

Ardisicrenoside D (2), white powder, mp $213-216^{\circ} \mathrm{C}$ (dec.), $[\alpha]_{\mathrm{D}}+23.4^{\circ}$. Its IR, ${ }^{1} \mathrm{H}$ - and ${ }^{13} \mathrm{C}-\mathrm{NMR}$ spectra indicated that compound $\mathbf{2}$ had the same aglycone as that 
of ardisicenoside $\mathrm{C}$, but differed in the oligosaccharide part (Tables I and II). Elementary analysis, the positive FAB-MS quasimolecular ions at $m / z \quad 1239[\mathrm{M}+\mathrm{H}]^{+}$, $1261[\mathrm{M}+\mathrm{Na}]^{+}, 1277[\mathrm{M}+\mathrm{K}]^{+}$and the ${ }^{13} \mathrm{C}, \mathrm{DEPT}$ $\mathrm{NMR}$ data gave a molecular formula of $\mathrm{C}_{58} \mathrm{H}_{94} \mathrm{O}_{28}$. Its ${ }^{1} \mathrm{H}$ - and ${ }^{13} \mathrm{C}$-NMR displayed five anomeric signals at $\delta$ $4.76(\mathrm{~d}, J=5.8 \mathrm{~Hz}), 4.90(\mathrm{~d}, 6.7), 4.98(\mathrm{~d}, 7.7), 5.45$ (d, 7.6), $6.44(\mathrm{~d}, 7.9)$ and $\delta 95.8,104.1,104.6,104.8$, and 107.5, respectively. Alkaline treatment of 2 as carried out for 1 yielded a glucose and a prosapogenin methyl ester (4). Further subjected to acidic hydrolysis, compound 4 afforded the same sapogenin (5) as $\mathbf{1}$, and the

TABLE III. ${ }^{1} \mathrm{H}-\mathrm{NMR}$ Data and the Selected Correlations in ROESY and HMBC for the Sugar Moieties in Compounds 1 and 2 (500 MHz in $\left.\mathrm{C}_{5} \mathrm{D}_{5} \mathrm{~N}, \delta\right)^{a)}$

\begin{tabular}{|c|c|c|c|c|c|c|}
\hline \multirow{2}{*}{ Sugar unit } & \multicolumn{3}{|c|}{ Ardisicrenoside C (1) } & \multicolumn{3}{|c|}{ Ardisicrenoside D (2) } \\
\hline & ${ }^{1} \mathrm{H}$ shift & ROESY & HMBC & ${ }^{1} \mathrm{H}$ shift & ROESY & НMBC \\
\hline \multicolumn{7}{|l|}{ 3-O-Sugar } \\
\hline \multicolumn{7}{|l|}{ Arabinose (A) } \\
\hline \multirow[t]{2}{*}{ A-1 } & $4.87 \mathrm{~d}(4.6)$ & A-H1 & A-H1 & $4.76 \mathrm{~d}(5.8)$ & A-H1 & A-H1 \\
\hline & & $\mathrm{C} 3-\mathrm{H}$ & $\mathrm{C}-3$ & & C3-H & C-3 \\
\hline $\mathrm{A}-2$ & $4.46 \mathrm{dd}$ & (Aglycone) & (Aglycone) & 4.52 & (Aglycone) & (Aglycone) \\
\hline A-3 & 4.40 & & & 4.24 & & \\
\hline A-4 & $4.51 \mathrm{~m}$ & & & 4.21 & & \\
\hline \multirow[t]{2}{*}{ A-5 } & 3.76 & & & 3.64 & & \\
\hline & 4.33 & & & $4.58 \mathrm{dd}(12.2,3.8)$ & & \\
\hline \multicolumn{7}{|l|}{$\begin{array}{l}\text { Glucose }(G) \\
\text { (Terminal) }\end{array}$} \\
\hline \multirow{2}{*}{ G-1 } & $5.25 \mathrm{~d}(7.7)$ & G-H1 & G-H1 & $5.45 \mathrm{~d}(7.6)$ & G-H1 & G-H1 \\
\hline & & $\mathrm{A}-\mathrm{H} 2$ & A-C2 & & A-H2 & $\mathrm{A}-\mathrm{C} 2$ \\
\hline G-2 & 3.94 & & & 4.04 & & \\
\hline G-3 & 4.19 & & & 4.21 & & \\
\hline G-4 & 4.10 & & & 4.20 & & \\
\hline G-5 & 3.94 & & & 3.98 & & \\
\hline \multirow[t]{2}{*}{ G-6 } & 4.25 & & & 4.40 & & \\
\hline & $4.38 \mathrm{dd}(11.6,2.7)$ & & & 4.52 & & \\
\hline \multirow{2}{*}{\multicolumn{7}{|c|}{$\begin{array}{l}\text { Glucose }\left(\mathrm{G}^{\prime}\right) \\
\quad \text { (Inner) }\end{array}$}} \\
\hline & $5.12 \mathrm{~d}(7.6)$ & $\mathrm{G}^{\prime}-\mathrm{H} 1$ & $\mathrm{G}^{\prime}-\mathrm{H} 1$ & $4.98 \mathrm{~d}(7.7)$ & $\mathrm{G}^{\prime}-\mathrm{H} 1$ & $\mathrm{G}^{\prime}-\mathrm{H} 1$ \\
\hline $\mathrm{G}^{\prime}-1$ & $0.12 \mathrm{~d}(1.0)$ & A-H4 & A-C4 & & $\mathrm{A}-\mathrm{H} 4$ & A-C4 \\
\hline$G^{\prime}-2$ & 4.14 & & & $3.91 \mathrm{dd}(8.6,8.2)$ & & \\
\hline$G^{\prime}-3$ & 4.08 & & & 4.18 & & \\
\hline$G^{\prime}-4$ & $3.99 \mathrm{dd}(8.8,9.5)$ & & & 4.17 & & \\
\hline$G^{\prime}-5$ & $3.71 \mathrm{~m}$ & & & $3.98 \mathrm{~m}$ & & \\
\hline \multirow[t]{2}{*}{$G^{\prime}-6$} & 4.18 & & & 4.25 & & \\
\hline & 4.34 & & & 4.42 & & \\
\hline \multicolumn{7}{|l|}{ Rhamnose (R) } \\
\hline \multirow[t]{2}{*}{$\mathrm{R}-1$} & $6.24 \mathrm{~s}$ & R-H1 & R-H1 & & & \\
\hline & & $\mathrm{G}^{\prime}-\mathrm{H} 2$ & $\mathrm{G}^{\prime}-\mathrm{C} 2$ & & & \\
\hline $\mathrm{R}-2$ & $4.16 \mathrm{~m}$ & & & & & \\
\hline R-3 & $4.54 \mathrm{~m}$ & & & & & \\
\hline $\mathrm{R}-4$ & $4.54 \mathrm{dd}(9.1,3.3)$ & & & & & \\
\hline R-5 & 4.13 & & & & & \\
\hline \multirow[t]{2}{*}{ R-6 } & $4.90 \mathrm{~m}$ & & & & & \\
\hline \multirow{2}{*}{\multicolumn{7}{|c|}{ Xylose (X) }} \\
\hline & & & & & & \\
\hline $\mathrm{X}-1$ & & & & $4.90 \mathrm{~d}(6.7)$ & $\begin{array}{l}\mathrm{X}-\mathrm{H} 1 \\
\mathrm{G}^{\prime}-\mathrm{H} 2\end{array}$ & $\begin{array}{l}\mathrm{X}-\mathrm{H} 1 \\
\mathrm{G}^{\prime}-\mathrm{C} 2\end{array}$ \\
\hline$X-2$ & & & & 3.99 & & \\
\hline$X-3$ & & & & 4.01 & & \\
\hline$X-4$ & & & & $4.11 \mathrm{~m}$ & & \\
\hline \multirow[t]{2}{*}{$X-5$} & & & & 3.69 & & \\
\hline & & & & 4.53 & & \\
\hline 30- $O$-Sugar & & & & & & \\
\hline Glucose $\left(G^{\prime \prime}\right)$ & & & & & & \\
\hline $\mathrm{G}^{\prime \prime}-1$ & $6.34 \mathrm{~d}(8.0)$ & & $\begin{array}{c}\mathrm{G}^{\prime \prime}-\mathrm{H} 1 \\
\mathrm{C}-30\end{array}$ & $6.44 \mathrm{~d}(7.9)$ & & $\begin{array}{c}\mathrm{G}^{\prime \prime}-\mathrm{H} 1 \\
\mathrm{C}-30\end{array}$ \\
\hline $\mathrm{G}^{\prime \prime}-2$ & 4.11 & & (Aglycone) & 4.21 & & (Aglycone) \\
\hline $\mathrm{G}^{\prime \prime}-3$ & 4.19 & & & 4.29 & & \\
\hline$G^{\prime \prime}-4$ & 4.21 & & & 4.30 & & \\
\hline$G^{\prime \prime}-5$ & 3.93 & & & 4.01 & & \\
\hline$G^{\prime \prime}-6$ & 4.24 & & & $4.34 \mathrm{dd}(12.5,4.0)$ & & \\
\hline & 4.34 & & & 4.43 & & \\
\hline
\end{tabular}

a) Assignment based upon COSY, HOHAHA, HETCOR experiments. 
TABLE IV. The Inhibitory Activity on cAMP Phosphodiesterase of the Compounds $\mathbf{1}-\mathbf{1 0}$

\begin{tabular}{cc}
\hline \hline Compounds & $\mathrm{IC}_{50}\left(\times 10^{-5} \mathrm{M}\right)$ \\
\hline $\mathbf{1}$ & 4.6 \\
$\mathbf{2}$ & 95.0 \\
$\mathbf{4}$ & 4.9 \\
$\mathbf{5}$ & 500 \\
$\mathbf{6}$ & 9.5 \\
$\mathbf{7}$ & 12.6 \\
$\mathbf{8}$ & 5.2 \\
$\mathbf{9}$ & 5.4 \\
$\mathbf{1 0}$ & 7.2 \\
Papaverine & 3.0 \\
& 3.0 \\
\hline
\end{tabular}

monosaccharides were identified as xylose, glucose and arabinose in the ratio of $1: 2: 1$ from GLC analysis. Therefore, ardisicrenoside $\mathrm{D}$ was also a bidesmosidic pentasaccharide, with one of the glucoses attached to the $\mathrm{C}-30$ through an ester bond and the other four ether-linked to the $\mathrm{C}-3$ position of the aglycone.

The same NMR techniques (COSY, HOHAHA, HETCOR, HMBC, and ROESY) were employed to establish the sequence of the tetrasaccharide. The ${ }^{13} \mathrm{C}$ shift differences between the individual sugar and that of the model compounds suggested that the xylose and one of the glucoses were in the terminal positions and that the C-2, 4 of arabinose and C-2 of the other glucose were glycosylated (Table II). From the HMBC experiment (the mixing time was set at $8 \mathrm{~Hz}$ ), significant long distance coupling between the $\mathrm{H}-1$ of xylose and $\mathrm{C}-2$ of the inner glucose, the $\mathrm{H}-1$ of the inner glucose and $\mathrm{C}-4$ of arabinose, and the $\mathrm{H}-1$ of the terminal glucose and $\mathrm{C}-2$ of arabinose were observed. ROESY results also supported these observations (Table III). The attachment of the tetrasaccharide chain to C-3 of the aglycone was further evident from the correlations in HMBC and ROESY, while the correlation existing between $\delta 6.44(\mathrm{H}-1$ of one of the glucoses) and 177.0 (C-30 of the aglycone) in HMBC substantiated that one of the glucoses was located at C-30 through an ester bond (Table III). Based upon their $\mathrm{H}-1$ vicinal coupling constants from ${ }^{1} \mathrm{H}-\mathrm{NMR}$ and their ${ }^{13} \mathrm{C}-\mathrm{NMR}$ data in comparison with those of the published model compounds, the anomeric configurations were determined to be $\beta$-D-xylopyranose, $\beta$-D-glucopyranose, and $\alpha$-L-arabinopyranose. The results from the ROESY experiment confirmed these conclusions. Thus, ardisicrenoside $\mathrm{D}$ (2) was established to be $3 \beta-O-\{\beta$-D-xylopyranosyl-( $1 \rightarrow 2)$ - $\beta$-D-glucopyranosyl- $(1 \rightarrow 4)$ - $[\beta$-D-glucopyranosyl- $(1 \rightarrow 2)]-\alpha$-L-arabinopyranosyl $\}-16 \alpha, 28$-dihydroxy-olean-12-en-30-oic acid 30- $O$ - $\beta$-D-glucopyranosyl ester.

The isolated triterpenoid saponins $(\mathbf{1}, \mathbf{2})$, their prosapogenin methyl esters $(3,4)$ and the sapogenin methyl ester (5), along with the former isolated triterpenoid saponins $(6-9)$ and the artifactual sapogenin (10) released from 8 and 9 under acidic hydrolysis ${ }^{5)}$ were evaluated for their inhibitory activity on cAMP phosphodiesterase as a primary screening test for medicinally potent compounds. ${ }^{16)}$ All the compounds except 2 and 4 showed strong inhibitory activity with their $\mathrm{IC}_{50}$ values compar- able to papaverine (Table IV). Experimental results showed that the inhibitory activity was influenced by the structures of both the aglycone and the sugar parts. For the compounds $(1-4)$ of the aglycone 5 the inhibitory activity decreased greatly if the terminal rhamnose was replaced by a xylose, while for compounds $(6-9)$ of the aglycone $\mathbf{1 0}$ the difference of the terminal sugars had almost no effect. Also, it seemed that the inhibitory activity of these compounds was not much affected by the different groups attached to $\mathrm{C}-20$.

\section{Experimental}

General All melting points were measured using a Yanaco microscope apparatus and are uncorrected. IR spectra were determined using a JASCO 7300 FTIR spectrometer. Optical rotations were measured using a JASCO DIP-370 digital polarimeter. EI (70 ev energy) and FAB mass spectrometry were conducted using JEOL D-300 and DX-303 mass spectrometers, respectively. ${ }^{1} \mathrm{H}$ - and ${ }^{13} \mathrm{C}-\mathrm{NMR}$ were recorded using a JEOL EX-400 $\left({ }^{1} \mathrm{H}\right.$ at $400 \mathrm{MHz},{ }^{13} \mathrm{C}$ at $\left.100 \mathrm{MHz}\right)$ or a JEOL A-500 FT-NMR ( ${ }^{1} \mathrm{H}$ at $500 \mathrm{MHz},{ }^{13} \mathrm{C}$ at $125 \mathrm{MHz}$ ) spectrometer. Standard JEOL pulse sequences were used for the 2D-NMR experiments. Chemical shifts were expressed in $\delta$ ( $\mathrm{ppm}$ ) downfield from tetramethylsilane as an internal standard, and coupling constants were reported in hertz $(\mathrm{Hz})$. TLC was carried out on Silica gel $60 \mathrm{~F}_{254}$, and spots were visualized by spraying with $10 \% \mathrm{H}_{2} \mathrm{SO}_{4}$ and heating. Diaion HP-20 (Mitsubishi Kasei), silica gel (Silica gel 60, Merck and Kieselgel $60 \mathrm{~F}_{254}$, Merck), and ODS (Chromatorex, 100-200 mesh, Fujisylisia) were used for column chromatography. Preparative HPLC was performed using an ODS column (Capcell pak ODS, Shiseido, 10 i.d. $\times 250 \mathrm{~mm}$, detector: reflective index). GLC: 25 SE-30 on Chromsorb $\mathrm{W}(60-80 \mathrm{mesh}), 3$ i.d. $\times 1.5 \mathrm{~m}$, column temperature $150^{\circ} \mathrm{C}$, carrier gas $\mathrm{N}_{2}$, flow rate $15 \mathrm{ml} / \mathrm{min}$.

Extraction and Isolation of Saponins The roots of Ardisia crenata Sims were purchased from Jiangxi, China in 1988. Dried powdered roots $(5 \mathrm{~kg})$ of Ardisia crenata were first defatted with petroleum ether, and then extracted with $\mathrm{CHCl}_{3}$ and $\mathrm{MeOH}$ under reflux conditions. The $\mathrm{MeOH}$ extract $(230 \mathrm{~g})$ was applied to a column of Diaion HP-20 $(1.5 \mathrm{~kg})$ and washed with $\mathrm{H}_{2} \mathrm{O}, 30,50,70$, and $100 \% \mathrm{MeOH}$ to give 50 fractions. The fractions containing saponins were combined according to their TLC behaviors. Each combined fraction was repeatedly chromatographed on silica gel columns with the solvent system $\mathrm{CHCl}_{3}-\mathrm{MeOH}-\mathrm{H}_{2} \mathrm{O}$, and then purified on an ODS column with $\mathrm{MeOH}-\mathrm{H}_{2} \mathrm{O}$ to give a TLC homogeneous saponin mixture. Further HPLC purification over ODS with $\mathrm{MeOH}-\mathrm{H}_{2} \mathrm{O}(45: 55)$ afforded ardisicrenosides $\mathrm{C}(1,102 \mathrm{mg})$ and D (2, $96 \mathrm{mg})$.

Ardisicrenoside C (1) White powder, mp $234-236^{\circ} \mathrm{C}$ (dec.), $[\alpha]_{\mathrm{D}}^{24}$ $+4.80^{\circ}(c=1.0, \mathrm{MeOH})$. Anal. Calcd for $\mathrm{C}_{59} \mathrm{H}_{96} \mathrm{O}_{28} \cdot 2 \mathrm{H}_{2} \mathrm{O}: \mathrm{C}, 54.94$; H, 7.82. Found: C, 55.01; H, 7.90. IR $v_{\max }^{\mathrm{KBr}} \mathrm{cm}^{-1}: 3410,2928,2871,1733$, $1635,1457,1374,1075$. FAB-MS $m / z: 1275[\mathrm{M}+\mathrm{Na}]^{+}, 1253[\mathrm{M}+\mathrm{H}]^{+}$. ${ }^{1} \mathrm{H}-\mathrm{NMR}$ (pyridine- $\left.d_{5}, 500 \mathrm{MHz}\right) \delta: 0.67(1 \mathrm{H}, \mathrm{d}, J=10.9 \mathrm{~Hz}, \mathrm{H}-5), 0.79$, $0.85,0.96,1.11,1.34,1.73$ (each $3 \mathrm{H}, \mathrm{s}, \mathrm{H}_{3}$ of C-25, C-26, C-24, C-23, C-29 and C-27), $2.65(1 \mathrm{H}, \mathrm{dd}, J=16.8,1.5 \mathrm{~Hz}, \mathrm{H}-18), 2.68(1 \mathrm{H}$, dd, $J=13.5,12.6 \mathrm{~Hz}, \mathrm{H}-19), 3.12(1 \mathrm{H}, \mathrm{dd}, J=11.6,4.3 \mathrm{~Hz}, \mathrm{H}-3), 3.54,3.63$ (each $\left.1 \mathrm{H}, \mathrm{d}, J=10.7 \mathrm{~Hz}, \mathrm{H}_{2}-28\right), 4.58(1 \mathrm{H}$, br s, H-16), $5.58(1 \mathrm{H}$, br t, H-12). ${ }^{1} \mathrm{H}$-NMR data for the sugar moiety are given in Table III. ${ }^{13} \mathrm{C}-\mathrm{NMR}$ data: Tables I and II.

Ardisicrenoside D (2) White powder, mp $213-216^{\circ} \mathrm{C}\left(\mathrm{dec}\right.$ ),$[\alpha]_{\mathrm{D}}^{28}$ $+23.4^{\circ}(c=1.00, \mathrm{MeOH})$. Anal. Calcd for $\mathrm{C}_{58} \mathrm{H}_{94} \mathrm{O}_{28} \cdot 3 \mathrm{H}_{2} \mathrm{O}: \mathrm{C}, 53.84$; $\mathrm{H}, 7.80$. Found: 53.87; H, 7.71. IR $v_{\max }^{\mathrm{KBr}} \mathrm{cm}^{-1}: 3407,2929,2878,1733$, $1653,1635,1457,1374,1074,1042$. FAB-MS $m / z: 1261[\mathrm{M}+\mathrm{Na}]^{+}, 1239$ $[\mathrm{M}+\mathrm{H}]^{+} .{ }^{1} \mathrm{H}-\mathrm{NMR}$ (pyridine- $\left.d_{5}, 500 \mathrm{MHz}\right) \delta: 0.72(1 \mathrm{H}, \mathrm{d}, J=11.6 \mathrm{~Hz}$, $\mathrm{H}-5$ ), $0.82,0.88,1.07,1.20,1.38,1.79$ (each $3 \mathrm{H}, \mathrm{s}, \mathrm{H}_{3}$ of C-25, C-26, C-24, C-23, C-29, C-27), 2.19 (1H, d, $J=11.3 \mathrm{~Hz}, \mathrm{H}-15), 2.76(1 \mathrm{H}, \mathrm{dd}$, $J=16.5,1.0 \mathrm{~Hz}, \mathrm{H}-18), 2.84(1 \mathrm{H}, \mathrm{dd}, J=13.4,12.5 \mathrm{~Hz}, \mathrm{H}-19), 3.15(1 \mathrm{H}$, dd, $J=11.5,4.2 \mathrm{~Hz}, \mathrm{H}-3), 4.64$ (1H, br s, H-16), 5.63 (1H, br t, H-12). ${ }^{1} \mathrm{H}-\mathrm{NMR}$ data for the sugar moiety are given in Table III. ${ }^{13} \mathrm{C}-\mathrm{NMR}$ data: Tables I and II.

Alkaline Treatment of Ardisicrenosides C (1) and D (2) Ardisicrenoside $\mathrm{C}(1,40 \mathrm{mg})$ was dissolved in $1 \mathrm{~N}$ sodium methoxide in $\mathrm{MeOH}$ $(6 \mathrm{ml})$ and then was kept overnight at room temperature $\left(20^{\circ} \mathrm{C}\right)$. After the reaction was completed, the solution was neutralized with a 
cation-exchange resin (Dowex 50W-X2, $\mathrm{H}^{+}$) and concentrated in a vacuum. Chromatography of the residue over ODS yielded a monosaccharide and a prosapogenin $(3,30.5 \mathrm{mg})$, eluting with $\mathrm{H}_{2} \mathrm{O}$ and $60 \% \mathrm{MeOH}$, respectively. The monosaccharide was treated with 1-(trimethylsilyl) imidazole at room temperature for $2 \mathrm{~h}$ and then $\mathrm{H}_{2} \mathrm{O}$ was added to decompose any excess reagent. The reaction product was extracted with hexane $(1 \mathrm{ml} \times 3$ times $)$. The hexane solution was subjected to GLC for identification of the sugar moiety by comparison with the TMSi derivatives of standard sugars. The monosaccharide was identified as D-glucose.

Using the same method, ardisicrenoside $\mathrm{D}(2,40 \mathrm{mg})$ resulted in prosapogenin $4(28.3 \mathrm{mg})$ and a glucose.

Prosapogenin 3 White powder, $\mathrm{mp} 225^{\circ} \mathrm{C}(\mathrm{dec}),[\alpha]_{\mathrm{D}}^{29}+4.0^{\circ}(c=1.0$, MeOH). Anal. Calcd for $\mathrm{C}_{54} \mathrm{H}_{88} \mathrm{O}_{23} \cdot 3 \mathrm{H}_{2} \mathrm{O}: \mathrm{C}, 55.93 ; \mathrm{H}, 8.18$. Found: C, 56.06; H, 8.22. FAB-MS $m / z: 1127[\mathrm{M}+\mathrm{Na}]{ }^{+}$. ${ }^{1} \mathrm{H}-\mathrm{NMR}$ (pyridine- $d_{5}$, $400 \mathrm{MHz}) \delta: 0.68(1 \mathrm{H}, \mathrm{d}, J=11.3 \mathrm{~Hz}, \mathrm{H}-5), 0.83,0.90,0.97,1.12,1.25$, 1.74 (each $3 \mathrm{H}, \mathrm{s}, \mathrm{H}_{3}$ of C-25, C-26, C-24, C-23, C-29, C-27), $2.34(1 \mathrm{H}$, $\mathrm{d}, J=14.5 \mathrm{~Hz}, \mathrm{H}-18), 2.70(1 \mathrm{H}, \mathrm{dd}, J=13.2,13.0 \mathrm{~Hz}, \mathrm{H}-19), 3.12(1 \mathrm{H}$, dd, $J=11.5,4.4 \mathrm{~Hz}, \mathrm{H}-3), 3.38,3.68$ (each $1 \mathrm{H}, \mathrm{d}, J=10.8 \mathrm{~Hz}, \mathrm{H}_{2}-28$ ), $3.70(3 \mathrm{H}, \mathrm{s}, \mathrm{COOMe}), 4.64(1 \mathrm{H}$, br s, H-16), $4.87(1 \mathrm{H}, \mathrm{d}, J=4.6 \mathrm{~Hz}, \mathrm{H}-1$ of Ara), $5.15(1 \mathrm{H}, \mathrm{d}, J=7.1 \mathrm{~Hz}, \mathrm{H}-1$ of inner $\mathrm{Glu}), 5.25\left({ }^{1} \mathrm{H}, \mathrm{d}, J=7.7 \mathrm{~Hz}\right.$, $\mathrm{H}-1$ of term. Glu), 5.46 (1H, brt, H-12), 6.24 (1H, s, H-1 of Rha). ${ }^{13}$ C-NMR data: Tables I and II.

Prosapogenin 4 White powder, $\mathrm{mp} 227^{\circ} \mathrm{C}(\mathrm{dec})$. $[\alpha]_{\mathrm{D}}^{29}+17.4^{\circ}$ $(c=1.0, \mathrm{MeOH})$. Anal. Calcd for $\mathrm{C}_{53} \mathrm{H}_{86} \mathrm{O}_{23} \cdot 3 \mathrm{H}_{2} \mathrm{O}: \mathrm{C}, 55.57 ; \mathrm{H}, 8.10$. Found: C, 55.58; H, 8.09. FAB-MS $m / z: 1113[\mathrm{M}+\mathrm{Na}]^{+} .{ }^{1} \mathrm{H}-\mathrm{NMR}$ (pyridine- $\left.d_{5}, 400 \mathrm{MHz}\right) \delta: 0.73(1 \mathrm{H}, \mathrm{d}, J=11.5 \mathrm{~Hz}, \mathrm{H}-5), 0.85,0.92,1.00$,

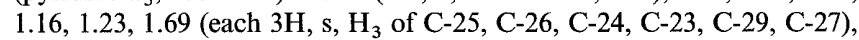
$2.65(1 \mathrm{H}, \mathrm{dd}, J=13.1,12.0 \mathrm{~Hz}, \mathrm{H}-19), 3.14(1 \mathrm{H}, \mathrm{dd}, J=11.5,4.0 \mathrm{~Hz}$, $\mathrm{H}-3), 3.33,3.62$ (each $\left.1 \mathrm{H}, \mathrm{d}, J=11.0 \mathrm{~Hz}, \mathrm{H}_{2}-28\right), 3.70$ (3H, s, COOMe), $4.55(1 \mathrm{H}$, br s, H-16), $4.70(1 \mathrm{H}, \mathrm{d}, J=5.8 \mathrm{~Hz}, \mathrm{H}-1$ of Ara), $4.84(1 \mathrm{H}, \mathrm{d}$, $J=7.1 \mathrm{~Hz}, \mathrm{H}-1$ of Xyl), $4.87(1 \mathrm{H}, \mathrm{d}, J=7.8 \mathrm{~Hz}, \mathrm{H}-1$ of inner Glu), 5.25 $(1 \mathrm{H}, \mathrm{d}, J=7.7 \mathrm{~Hz}, \mathrm{H}-1$ of term. Glu $), 5.60\left(1 \mathrm{H}\right.$, br t, H-12). ${ }^{13} \mathrm{C}-\mathrm{NMR}$ data: Tables I and II.

Acidic Hydrolysis of Prosapogenins 3 and 4 Compound $3(25 \mathrm{mg})$ was heated in a mixture of $2 \mathrm{~N} \mathrm{HCl}(4 \mathrm{ml})$ and $\mathrm{MeOH}(4 \mathrm{ml})$ at $80^{\circ} \mathrm{C}$ for $4 \mathrm{~h}$ in a water bath. After $\mathrm{MeOH}$ was removed, the solution was extracted with EtOAc $(4 \mathrm{ml} \times 3)$. The extraction was washed with water, and then combined to give a white powder. Purification of the product over silica gel and crystallization from $\mathrm{MeOH}$ afforded a sapogenin $(5,10 \mathrm{mg})$. The monosaccharide composition was determined by GLC analysis to be L-arabinose, D-glucose and L-rhamnose $(1: 2: 1)$ as their TMSi derivatives.

Using the same method, compound $4(10 \mathrm{mg})$ was hydrolyzed to give the same sapogenin $5(4 \mathrm{mg})$ and the monosaccaharides were determined to be L-arabinose, D-glucose and D-xylose $(1: 2: 1)$.

Sapogenin (5) Colorless needles, mp $243-245^{\circ} \mathrm{C},[\alpha]_{\mathrm{D}}^{24}+55.2^{\circ}$ $(c=0.5, \mathrm{MeOH})$. FAB-MS $m / z: 503[\mathrm{M}+\mathrm{H}]^{+}$. EI-MS (rel. int. \%): $m / z$
$484\left[\mathrm{M}-\mathrm{H}_{2} \mathrm{O}\right]^{+}(3.0), 454$ (45.3), 439 (28.9), 421 (6.46), 264 (93.9), 245 (81.5), 207 (30.0), $185(69.7) .{ }^{1} \mathrm{H}-\mathrm{NMR}$ (pyridine- $\left.d_{5}, 400 \mathrm{MHz}\right) \delta: 0.90$ $(1 \mathrm{H}, \mathrm{d}, J=11.2 \mathrm{~Hz}, \mathrm{H}-5), 0.97,1.01,1.05,1.23,1.31,1.83$ (each $3 \mathrm{H}, \mathrm{H}_{3}$ of C-25, C-26, C-24, C-23, C-29, C-27), $2.79(1 \mathrm{H}, \mathrm{dd}, J=13.3,12.8 \mathrm{~Hz}$, H-19), 3.47 (1H, dd, $J=10.6,5.4 \mathrm{~Hz}, \mathrm{H}-3$ ), 3.49, 3.78 (each $1 \mathrm{H}, \mathrm{d}$, $\left.J=10.8 \mathrm{~Hz}, \mathrm{H}_{2}-28\right), 3.74$ (3H, s, COOMe), 4.74 (1H, br s, H-16), 5.55 (1H, brt, H-12). ${ }^{13} \mathrm{C}-\mathrm{NMR}$ data: Table I.

Assay of cAMP Phosphodiesterase Activity The phosphodiesterase activity was assayed using a modification of the method of Thompson and Brooks as previously described. ${ }^{16)}$ The assay consisted of a two-step isotopic procedure. Tritium-labeled cAMP was hydrolyzed to 5'-AMP by phosphodiesterase, and the $5^{\prime}$-AMP was then further hydrolyzed to adenosine by snake venom nucleotidase. The hydrolysate was treated with an anion-exchange resin (Dowex AG1-X8; Bio-Rad) to adsorb all charged nucleotides and to leave $\left[{ }^{3} \mathrm{H}\right]$ adenosine as the only labeled compound to be counted.

Acknowledgments We are grateful to Dr. M. Takayama for the MS measurements and to Miss N. Kurokawa for the elemental analyses. Z. Jia also wishes to acknowledge his scholarship (1993-1994) from this university.

\section{References}

1) Zhong Yao Da Ci Dian, Jiangsu New Medical College, Shanghai Scientific Publishing House, Shanghai, China, 1977, p. 913.

2) C. Jansakul, H. Baumann, L. Kenne, G. Samuelsson, Planta Med., 53405 (1987).

3) M. Wang, X. Guang, X. Han, S. Hong, Planta Med., 58, 205 (1992).

4) N. D. Tommasi, S. Piacente, F. D. Simone, C. Pizza, Z. Zhou, J. Nat. Prod., 56, 1669 (1993).

5) Z. Jia, K. Koike, T. Ohmoto, M. Ni, Phytochemistry, in press.

6) B. C. Pal, G. Roy, S. B. Mahato, Phytochemistry, 23, 1475 (1984).

7) L. R. Hahn, C. Sanchez, J. Romo, Tetrahedron, 21, 1735 (1965).

8) D. G. Davis, A. Bax, J. Am. Chem. Soc., 107, 2820 (1985).

9) A. Bax, M. F. Summers, J. Am. Chem. Soc., 108, 2093 (1986).

10) A. Bax, D. G. Davis, J. Magn. Reson., 63, 207 (1985).

11) P. K. Agrawal, Phytochemistry, 31, 3307 (1992).

12) P. K. Agrawal, D. C. Jain, R. K Gupta, R. S. Thakur, Phytochemistry, 24, 2479 (1085).

13) B. Capon, D. Thacker, Proc. Chem. Soc. London, 1964, 369.

14) J. P. Waltho, D. H. Williams, S. B. Mahato, B. C. Pal, J. C. J. Barna, J. Chem. Soc., Perkin Trans 1, 1986, 1527.

15) H. Ishii, I. Kitagawa, K. Matsushita, K. Shirakawa, K. Tori, T. Tozyo, M. Yoshikawa, Y. Yoshimura, Tetrahedron Lett., 22, 1529 (1981).

16) T. Nikaido, T. Ohmoto, U. Sankawa, T. Tomimori, Y. Miyaichi, Y. Imoto, Chem. Pharm. Bull., 36, 654 (1988). 